\title{
The Character Education in Islamic Modern Boarding School
}

\author{
Dewi Ratnasari \\ Graduate School \\ Universitas Negeri Yogyakarta \\ Yogyakarta, Indonesia \\ dewiratnasari101992@gmail.com
}

\author{
Dyah Kumalasari \\ Graduate School \\ Universitas Negeri Yogyakarta \\ Yogyakarta, Indonesia \\ dyahkumala@gmail.com
}

\begin{abstract}
This study aims to look at portraits of character education in schools using descriptive qualitative method with the case of study approach at boarding school of Baitussalam IT high school, Prambanan Yogyakarta. Character education for learners cannot be realized only in the classroom but is also supported by habits in daily life as what is applied in IT high school modern boarding school Baitussalam. The Muslim personal character becomes a reflection in instilling a noble character education to the students with the support of school policies and activities undertaken by the learners.
\end{abstract}

Keywords - Character education, personal Muslim character, Islamic modern boarding school

\section{INTRODUCTION}

The development of the world that occurs in this era brings a great influence on humans in various things, both positive and negative, especially in the pattern of human behavior. Man, as a perfect being given the mind to think to the better than it should man realize it. Moral degradation affects the world especially the State of Indonesia, the people of Indonesia lately easily provoked with simple things, impatient, aggressive, easily rioted, more and more domestic conflict, increasingly fragile interpersonal relationships [1]. These negative phenomena begin to spread in the world of education so that the impact on the moral crises of learners, such as free sex among adolescents, the lack of courtesy in speech, and the attitude of dishonesty when taking the test is the habit of cheating.

Education has a big duty in shaping the character of the learners so that they become persons who have moral, it is as set out in the law of the Republic of Indonesia Number 20 of 2003 on National Education System listed in chapter II of basic, function, and objective contained in article 3 that is national education functions to develop the ability, character and civilization of nation in order to educate the life of nation, aiming for the development of potential learners to become human faithful and devoted to God Almighty, have a noble character, healthy, knowledgeable, capable, creative, independent, and become citizens of democratic and responsible.

From the purpose of education, moral education is one of the important aspects to form the attitude of the future generations. Moral education is not being a priority, sometimes ruled out and considered unnecessary because of more attention to intellectual ability, but in fact intelligence is not enough to make the excellent younger generation and can grow rapidly to current developments. That is why character education is needed as a moral support of the younger generation to become persons who have a broadminded and polite personality.

Not many people realize that the education system in Indonesia is just preparing the students to enter the college level or just for those who do have talent on academic potential (high IQ size) only. This can be seen from the subjects that are directed to the development of academic dimensions of learners who are often measured by the ability of logic-mathematics and abstraction (language skills, memorization, abstraction or IQ size). On the other hand, the reality shows that wherever humans on earth, who have an IQ above the number 120 is no more than 10 per cent of the population [2].

During this time, Indonesia's education is issued to be Western-oriented as well as the references also refer to the West. If it is looked at the actual phenomenon, the value contained by the West and East is very different. The concept of value in the West refers on the sense of mind then all kinds of good values such as political value, social value, economic value, value of knowledge, moral values, and other values are based on mind. On the other hand, in the East religion is becoming the base value, where all forms of values, political values, social values, economic value, value of knowledge, and moral values cannot be separated by religion [3]. Thus, there is a difference of perception in the concept of value, as well as to the character. Elements of character values applied in the West and considered good not necessarily the same as that happened in the East and vice versa not necessarily the value is considered good.

West oriented education effects on learners in implementing their behavior indirectly based on educational programs obtained. Thus, it is needed to reconstruct the orientation of education in Indonesia to make a generation with noble character so that not only intellectually intelligent but also spiritually intelligent, 
then to create a noble character man, Indonesia must have a soul-touching education system. It is in accordance with Islamic education which aims to form a noble person with good character.

Character education cannot be separated from the awakening of moral and religious values to the learners. The application of the importance of values, morals, and religions that integrate faith and piety in accordance with the main pillar of education is to create a change towards the better future. Education aims to make people free, free from restraints, ignorance, oppression, and backwardness to the ideal human and dignified. Therefore, the morale and character of the young generation must be educated and guided so that they can bring benefits to the nation and state. In this case religion is an important role, so the guidance of the character of the learners must be in line with the teaching of religion. Thus, character education cannot be separated from the religious aspect. It is like a coin that both sides need and complete each other. If one side of the coin does not exist, it has no value at all. Similarly, between character education and Islam.

The universal values of religion which are the basis of character education are important because one's belief in values based on his religion can be a strong motivation in character building, and learners' character are constructed to reflect their respective religions, so that learners have thoughts and morals accordingly with the guidance of religious teachings [4]. Islamic education has a mission to humanize human beings, thus bringing human beings who are beneficial in all things with their potential based on the guidance of Allah and the Prophet and perform his role well to be the best human being. Based on the background of the issue, this article tries to examine the character education in Islamic modern boarding school.

\section{CHARACTERISTICS OF EDUCATION AT ISLAMIC MODERN BOARDING SCHOOL BAITUSSALAM IT HIGH SCHOOL}

The background of Baitussalam boarding school was a Ma'haj which means non-formal education institutions that focus only on Islamic learning. The next stage of this boarding school is growing not only focusing on Islamic education, but also transformed into a formal education institution in 2014, so boarding school Baitussalam undergoing its role as one of the institutions named Baitussalam IT high school with the concept of modern boarding school. The applied curriculum is divided into 3 categories; school curriculum, Islamic curriculum, and SIT (Integrated Islamic School) curriculum. The office curriculum refers to the policies of the department, the Islamic curriculum adopts some rules from Gontor boarding school, and the SIT curriculum adopted because this school is incorporated in JSIT (Integrated Islamic School Network) with the mission and vision statement derived from there.
The vision is to form a great Muslim person with the provision of science Qouliyah, Kauniyah and life skills which are environmentally sound and bring the grace to the universe, in order to realize the missions, as follows: (1) Organizing Islamic education in an integrated and sustainable way to form a Muslim with strong aqidah, obedient worship and good personality; (2) Creating a conducive environment to the implementation of quality Islamic education; (3) Provide the students with knowledge and various skills to be able to continue to a higher level; (4) Establish generation of great Muslims, who are able to apply their knowledge for ummah.

In addition, there are also five soul Baitussalam namely: a) sincerity; b) simplicity; c) self-reliance; d) struggle; and e) Ukhuwah Islamiyah. While the five rules of PPM Baitussalam namely; a) orderly heart; b) orderly time; c) orderly language; d) orderly environment; and e) orderly KBM. Efforts to realize the vision, mission and Panca soul can be realized with the support of teachers and parents who work together to instill them to the children. In addition, the formulation of the curriculum and learning process are also important sections in realizing learner with high moral.

\section{THE LEARNING PROCESS AT THE MODERN ISLAMIC BOARDING SCHOOL BAITUSSALAM IT HIGH SCHOOL}

Learning is differentiated into the aspects of school lessons and diniyah or boarding lessons, both taught at 06.30 pm until 15:00 pm. School lessons are oriented to the school's curriculum, while the lessons of diniyah/boarding include: tahfidz, personal mentoring program, nahwu, siroh nabawiyah, mafruzod, muthala'ah, imlaq, hadith.

A. Tahfidz in the form of recitation program of AL Qur'an which is memorizing in front of the dormitory coach which is done after maghrib prayer and after isya prayer by which the recitation will be corrected directly.

B. Muslim mentoring program, which is held every week with the division of groups that each group is accompanied by a teacher as a classroom assistant. The content of this class is related to characters based on Islamic values or identical with the personal character of Muslims and applied by santri in everyday life.

C. Nahwu and shorof, i.e. learning the rules of Arabic or Arabic grammar so they can use Arabic properly.

D. Siroh nabawiyah, which examines the history of Islam that existed in various countries, especially the areas tracked by the Prophet Muhammad saw and the Prophet's journey along with his companions in spreading Islam to all parts of the world. 
The special program is; tahfidz 1 juz for a year (minimum), personal mentoring program (mentoring), dai/da'iyah ready to use, Arabic and English. Tahfidz program is one of the things that becomes priority in school. It is proved that the students who have not been able to complete the memorization within a predetermined time, they will not have holiday until they complete the target. Evaluation of boarding lessons was conducted through question and answer verbally between teacher and student that held before the written exam. It is hope that students can focus maximally with diniyah exams so that not only intelligent intellectually but also must be intelligent spiritually. The implementation of evaluation by oral means to minimize the occurrence of cases of fraud and the reality of honesty understanding of students is clear on the personal respective.

\section{CHARACTER EDUCATION BASED ON MODERN BOARDING SCHOOL AT BAITUSSALAM IT HIGH SCHOOL}

In line with the vision, mission and panca soul, Baitussalam IT high school educates the learners to have akhlaqul karimah with 10 personal characters of Muslims, as follows:

\section{A. Salimul Aqidah (Right Aqidah)}

The key word of this reflection is the aqidah which means binding the heart to something as if attached to it. This means steadiness, firmness, and robustness against the pillars of Islam that are firmly rooted and not lost due to shock, hesitate or doubt. The principles of aqidah are faith in God, the angels, the holy books, the apostles, the final day and the fate of good and evil. Faith is a firm belief that has no doubt about it. Thus, learners are taught to always hold fast to the Creator along with all the rules that have been established. The two sentences of the shahadah are the pillars that must be completely hand-held by each learner and the grips will be strong if equipped with a supportive environment, even though leaving school will remain firm without being impaired by opposing traits.

\section{B. Sahihul Ibadah (Right Worship)}

The root of the word worship is submissive and obedient to the provisions of Islam. Ibn Qayyim writes that worship comprises two factors, namely the peak of love, and the peak of submission and obedience. Worship has a broad meaning that is doing all the work that leads to goodness. Then learners are directed to always realize the positive values. The characters contained in this reflection include, greeting when meeting, answering when being called, fulfilling invitation, praying for whoever in sneezing, visiting when someone is sick, mourning of died body, keeping promises to others, advising when someone asked for advice, keeping from ghibah, wanting good for others just as good for himself, hating evil over others just as bad as over himself, kind thinking (husnuzhan), stealing forgiveness and piety for others, keeping others secret, helping when needed, guiding in times of trouble, guarding when travels, being gentle to when loaded, forgiving if other apologizes, lends if others asks for it, fulfills right without slowing it down, humbles and does not disparage others, cherishes and rewards others, hears his words and cares for them, do not oppose others and neglect them [5].

\section{Matinul Khuluq (Sincere Morals)}

Morals are human personality which are good and bad, while sincere moral is a good and strong human nature that cannot be shaken by any event. The way to achieve moral perfection is to follow the life of the Prophet, so students are provided with understanding of the reflection of the moral of Rasulullah with the motto "Muslim is a strong person and a morality rabbani". Thus, learners not only have enough understanding but also need to implement in the real life so that they are in harmony between knowledge, words, and deeds. For example, learner understands that worship is a duty to be performed. Then to prove, it can be seen from the conviction to fulfill it.

\section{Qawiyyul Jismi (Strong Physical)}

Humans are endowed with various potentials, such as having strong muscle, spiritual strength, instinctual knowledge, potential sense, emotional ability, and many other potentialities. Everything must be empowered in productive acts to utilize its potential well and maximally. Then to achieve, it is needed a prime body. One of the efforts is to exercise regularly. It is also in accordance with the advice of health science as the body desperately needs to keep the stamina awake and not easily attacked by diseases. In Baitussalam IT high school, it is given schedule for exercising after ashar time or afternoon in order to keep the body with the activities in school. In addition, extracurricular supported this character is the presence of archery, SIT scout, soccer, and martial arts. The most interesting program for the learners is martial arts.

\section{E. Mutsaqqaful Fikri (Broad Insight)}

In general, mutsaqqaful fikri means the ability possessed by someone to obtain information and skills to know the truth of things and utilize it. This kind of skill is one of the capabilities in understanding the theoretical sciences. This kind of Muslim generation can make a big contribution to their homeland, which have a balance orientation between world life and after life, in understanding the concept of science from various aspects so it can be collaborated well. Baitussalam IT high school tries to apply this character which is balancing between the government curriculum and diniyah curriculum, each of which both have important aspects to be taught to the learners.

\section{F. Qadirun Alal Kasbi (Independent in Income)}

The nature of qadirun alal kasbi is necessary as other properties in aspects of knowledge, feelings and work skills. This aspect is trained and practiced since early through the efforts in acquiring various skills, 
loving business, working, saving, and investing. Providing teaching and job training to learners has several benefits to them, including:

1. Familiarize learners to grow in self-reliance

2. Unaccustomed to idle and has unused free time

3. Does not depend on others

4. Accustomed to saving and not wasteful

5. Form of investors mental

6. Free from various problems during the teenage years due to her busyness and seriousness

7. Accustomed enough with a little livelihood because of the appreciation of the treasures in life

8. Does not depend on employment status (employee) but try to work alone with trade

9. Accustomed to the nature of trust, managerial skills, honest, and commitment with promises

10. Able to choose a work with applicative exercises and determine his choice of education realistically

11. Become person that gives benefit in life, selfsufficient and provide support to others

12. Accustomed to surviving and confident

Thus, learners are motivated to have an income that starts from simple things in self-training. In its application, IT high school has culinary and fashion extracurricular as one of the means for students to develop their potential and can be used for the future that can be used as fields of income independently and have knowledge related to the work of halal and haram.

\section{G. Munazzamun Fi Syu'unihi (Regular Affairs)}

This character is something that should be considered in everyday life. It is because the affairs are more than the time available so discipline in managing affairs is necessary for a Muslim. Doing school and boarding activities that demand so much learners to sort through the affairs on a priority scale, so that the affairs will be fulfilled with the time available. Mistakes in indiscipline will affect the life that is lived due to all the barriers that must be realized.

\section{H. Harishun Ala Waqtihi (Clever in Keeping Time)}

Time is the most valuable thing because it cannot be repeated, it has become a human duty in keeping time with the best. The clever character of keeping time is closely related to a regular matter because if one of these things is wasted it will destroy each other. Time consists of past, present and future. The past is the time that has passed, and it is impossible to ask for it again, so that if it passes without the obligation that is fulfilled it will be in vain. The present must really focus on the now obligation to avoid being wasted like the past. Therefore, in teaching the learners' characters, learners should do the activities at a predetermined time, such as praying in congregation in the mosque and if too late, they will get the sanctions.

\section{Nafiun Lighairihi (Beneficial for Others)}

A Muslim is a person who always brings goodness to the environment not to be a person who bring badness. SMA IT Baitussalam teaches the students to be a figure that is always being waited by others, such as helping other who needs help and care about the condition of other who is experiencing distress.

\section{J. Mujahidun Linafsihi (Controlling Desire)}

Controlling desire is the characteristic that can make person closer to the Creator. This character is very hard to be realized by humans including learners. Various kinds of desires are embedded in the learners, it is necessary to understand them in order to control them as best as possible. One effort in controlling desire is when eating, learner must have the nature of care because their friends will also eat with him then the portion of the meal does not exceed the portion that has been determined.

The above points are the pillars that are noticed by Baitussalam IT high school in an effort to produce students who have noble character. Realizing 10 personal characters of Muslims can be seen from daily life of the learners, the chief, and the headmaster. One example of the leadership is making the policy that the girls' classroom and boys' classroom are distinguished, this also applies to the office of ustadz and ustazah. Dormitory also has policies that can train santri in instilling noble character, for example santri required to get up at $03.30 \mathrm{a} . \mathrm{m}$. to perform tahajud prayer followed by dawn prayer together in mosque for boys' learners and in musalla / dormitory for girls' learners. After that, they do morning dhikr together and get ready to go to school because learning started at $06.30 \mathrm{pm}$. For students who are not disciplined or late, they will be given sanction that they cannot enter the school environment. They should stand in front of the gate for 30 minutes to 1 hour until the gate opens.

Learning started at 06.30 to 15.00 followed by ashar prayers congregation in the mosque and then the afternoon activities such as sports or other private activities, then praying maghrib together in the mosque and memorize or murojaah / repeat memorization to dormitory coach then pray isya together, then learn independent in the classroom until 22:00 hours and rest. Violating the rules will be sanctioned, such as not performing prayers together, late coming to school, cheating, taking other people's property without permission, clothes not tidy, and others. It is hope that the learners accustomed to performing useful activities and embedded great character, because the moral must sow through the habituations to flourish and produce results in accordance with the desired.

Character education is also instilled through school extracurricular activities, namely scouting (SIT scouting), martial arts (holy sites), MTQ, fashion, OSN mathematics, OSN chemistry, youth scientific work, teenage pen world, batik, cooking, archery, and English 
club. Scout and martial arts activities are programs that must be followed by male students, while for extracurricular female students who are required are scouts and archery.

Character formation for students needs to be habituated to daily activities. These activities are carried out both in the dormitory and at school accompanied by the dormitories and the teacher council. The Baitussalam IT High School mentoring program consists of congregational prayers at the mosque, Friday prayers at the mosque, dhuha prayer, midnight prayer, tilawatil qur'an, tahfidzul qur'an (memorizing the Qur'an), muraja'ah (repeating memorization), tajwid and tahsin, wirid morning and evening (Al Ma'tsurat), mentoring Islam, muhadharah (Arabic speech), muhadatsah (Arabic conversation), mufradat / vocabulary, riyadhah (sports), mabit / jalasah ruhiy, AL Qur'an coaching, recreation, grand speech, Baitussalam carnival, i'tikaf, mukhayyam (camping) art, and organization. These activities are carried out to develop students' personalities so that they have a soul that is always close to Islamic character. Based on the existing programs, schools try to create Islamic routines in schools and dormitories.

In addition, the evaluation was carried out with several assessments, one of which was the assessment of noble character and personality which was summarized in 9 aspects of assessment which included discipline, cleanliness, responsibility, courtesy, confidence, leadership, social relations, honesty, and the conduct of ritual worship. This assessment is written on the boarding report card filled by the dormitory coach.

The education in modern boarding schools is not only focused on Islamic learning but has a big task in educating students to have Islamic insights and general insight. Islamic boarding school is one of the strategic places to instill the character of Islam to students because it can pay attention to students' routines for 24 hours. Baitussalam IT High School is a boarding school in it containing official and pondok or diniyah contents. Policies that are applied at school refer to Islamic guidance both in terms of learning in class and outside of hours of learning.

Planting Islamic-based character values to students refers to the 10 pillars of Muslim personal character, including: salimul aqidah (right aqidah), sahihul ibadah (right worship) matinul khuluq (sincere morals), qawiyyul jismi (strong physical), mutsaqqaful, fikri (broad insight), qadirun alal kasbi (independent in income), munazzamun fi syu'unihi (regular affairs), harishun ala waqtihi (clever in keeping time), nafiun lighairihi (beneficial for others), and mujahidun linafsihi (controlling desire).

In addition, character values are instilled through extracurricular activities and boarding activities. Programs run by schools and dormitories try to form students who are close to the guidance of Islam to produce a person who is rabbani based on the Qur'an and hadith. The evaluation is carried out by considering the noble moral aspects consisting of discipline, cleanliness, responsibility, courtesy, confidence, leadership, social relations, honesty, and the implementation of ritual worship. Thus, school culture has a mission to bring students and educators closer to religious habits.

\section{CONCLUSION}

Indonesia is a predominantly Muslim country, the aspect contained must also base on Islam in order to produce human beings which have great and noble character, including in the world of education. Characters implanted in schools are oriented to Western education so that the values known to students are likewise. Schools need to design the character values in accordance with religion especially Islam to be applied to students from an early age. The purpose of national education is in line with Islamic education which wants to form human beings who have good moral, ethics and humanize others. One of the schools that tries to form Islamic-based character education is modern boarding school of Yogyakarta Baitussalam IT high school. Character education is not only to be conveyed and embedded in the classroom, but it needs to be taught outside the classroom. Boarding schools have a great chance to be more intensive in teaching and implementation those characters. Yogyakarta Baitussalam IT high school uses government curriculum and boarding or diniyah curriculum, and the character education that tries to be planted there realizing 10 Muslims characters to realize students with rabbani character.

\section{REFERENCES}

[1] Wahyu., "Masalah dan Usaha Membangun Karakter Bangsa", Jurnal Komunitas, 3 (2), 2011, pp. 138-149.

[2] Muslich, M., "Pendidikan Karakter: Menjawab Tantangan Krisis Multidimensional", Jakarta: Bumi Aksara, 2011.

[3] Kumalasari, D., "Pendidikan Karakter Berbasis Agama". http://staffnew.uny.ac.id/upload/132304482/penelitian/PEN DIDIKAN+KARAKTER+BERBASIS+AGAMA.pdf

[4] Azzet, A. M., "Urgensi Pendidikan Karakter di Indonesia: Revitalisasi Pendidikan Terhadap Keberhasilan Belajar dan Kemajuan", Yogyakarta: Ar-Ruzz Media, 2013.

[5] Isa, M.H \& Manshur, A., "Syarah 10 Muwashafat: Penjelasan Lengkap 10 Karakter Muslim Tangguh", Laweyan: Era Adicitra Intermedia, 2017. 